\title{
POŠTA
}

TELEKOMUNIKÁCIE A

ELEKTRONICKY OBCHOD

\section{ANALÝZA A NÁVRH ALGORITMU PRE VÝBER PRIPOJENIA DO SIETE INTERNET}

\author{
Radovan Madleňák, Petra Senková*
}

\section{Úvod}

Prípady algoritmov sú známe $\mathrm{z}$ bežného života, hoci si ani neuvedomujeme, že ide o algoritmus, napr. technologický postup výroby, niektoré zákony a vyhlášky, štátne normy, matematické vzorce. Najznámejším a najbežnejšie používaným algoritmom je napríklad kuchárska kniha (recepty), presný postup ako z jednotlivých ingrediencií pri správnej príprave pripravíme jedlo.

\section{Vlastnosti a formy algoritmov}

Algoritmus je zápis definujúci výpočtový proces vedúci od menitel’ných vstupných údajov až $\mathrm{k}$ žiadaným výsledkom. Táto definícia síce presne vystihuje podstatu a účel algoritmu, je však úzko špecializovaná. Obmedzuje sa len na výpočtový proces. Algoritmy však nepoužívame len pri príprave programov pre počítače, ale ich použitie je všeobecné. Pomocou algoritmu totiž môžeme presne definovat' akýkol'vek determinovaný proces. Algoritmus je v podstate vyjadrenie postupnosti krokov a inštrukcií, ktoré vedú k riešeniu určitého problému. Pritom je nepodstatné, či je toto vyjadrenie slovné, grafické, alebo v inštrukciách konkrétneho programovacieho jazyka.

Každý algoritmus (opis riešenia procesu) vykazuje niektoré spoločné znaky:

- algoritmus sa skladá z jednotlivých krokov,

- počet krokov musí byt' konečný,

- algoritmus musí byt' presný a zrozumitel'ný.

Z toho môžeme odvodit' základné vlastnosti algoritmu [5]:

- jednoznačnost'- každý krok algoritmu musí byt' presne definovaný a nesmie dovol'ovat' viacej výkladov, teda nesmie pripúšt'at' pochybnost' o tom, ako postupovat' d'alej,

- Všeobecnost' - algoritmus musí vyhovovat' riešeniu všeobecnej skupiny úloh, musí vychádzat' z menitel'ných vstupných údajov, t. j. musí to by popis riešenia nie len jednej úlohy, ale celej skupiny príbuzných úloh líšiacich sa od seba len vstupnými údajmi,

- rezultatívnost' - algoritmus musí vždy vyústit' do nejakého riešenia, a to po konečnom počte krokov.

Okrem základných vlastností sa na algoritmus kladú aj d’alšie požiadavky:

\footnotetext{
* Ing. Radovan Madleňák, PhD., Ing. Petra Senková, Katedra spojov, Fakulta prevádzky a ekonomiky dopravy a spojov, Žilinská univerzita v Žiline, Univerzitná 1, 01026 Žilina, Slovenská republika, tel.: +421/41/5133124, fax: +421/41/5655615, e-mail: Radovan.Madlenak@fpedas.uniza.sk
} 
- zrozumitel'nost' - použitie takých prostriedkov na zápis algoritmu, ktoré by mali byt' zrozumitel'né rôznym pracovníkom, ktorí budú s algoritmom pracovat' (analytik, programátor, používatel', oponent...),

- $\quad$ správnost' - algoritmus musí úplne a správne riešit' danú úlohu,

- výhodnost' (efektívnost') - zmyslom efektívnosti je minimalizovat' nároky na spracovanie činnosti podl'a algoritmu. Efektívnost' môžeme posudzovat' z rôznych hl’adísk (minimalizácia finančných nárokov, minimalizácia spotreby energie, minimalizácia nárokov na personálne alebo materiálne vybavenie...), prípadne sa snažíme optimalizovat' vzájomný vzt'ah viacerých hl'adísk. Táto požiadavka je často v rozpore s požiadavkou na štruktúrovanost' (prehl'adnost', modulárnost', usporiadanost') algoritmu,

- modifikovatel'nost' - algoritmus by mal byt' vytvorený tak, aby sa dal l'ahko modifikovat' pri potrebnej zmene vyvolanej zmenou podmienok riešenia (vonkajších, vnútorných),

- štruktúrovanost' - požiadavka na vnútornú štruktúru algoritmu, ktorý by mal byt' rozdelený na relatívne samostatné, ale logicky nadväzujúce celky, ktoré riešia vždy príslušnú čast' algoritmu, požiadavka súvisí so zrozumitel'nost'ou a modifikovatel'nost'ou, dobre štruktúrovaný algoritmus je zrozumitel'ný a l'ahko modifikovatel'ný (opravitel'ný) [5].

Na zápis algoritmov sa používa vel'a techník, z ktorých najpoužívanejšie sú:

- Slovný opis - najjednoduchší spôsob zachytenia a vyjadrenia algoritmu. Takto bývajú často zachytávané algoritmy $\mathrm{v}$ bežnom živote. Pri slovnom opise sú verbálne vyjadrené jednotlivé kroky, príp. podmienky na ich uskutočnenie a postupnost' je zrejmá zo zoradenia krokov v texte.

- Symbolický jazyk - často sa používa na zápis algoritmov v projekčnej praxi. Symbolické jazyky do určitej miery pripomínajú programovacie jazyky. Má presne stanovenú syntax (spôsob zápisu operácí́, formuláciu podmienok, atd’.) i sémantiku (repertoár a význam operácií ktoré sa môžu použit').

- Vývojový diagram - je metódou grafického znázornenia algoritmu, zachytávajúcou jeho štruktúru a nadväznost' operácií. Rozlišujeme vývojový diagram úlohy, ktorý opisuje algoritmus celej úlohy, skladajúci sa zčiastkových častí (programov), vývojový diagram programu (algoritmu), ktorý graficky znázorňuje logickú stavbu (algoritmus) čiastkovej časti úlohy - programu, a vývojový diagram údajov, ktorý graficky znázorňuje tok dát systémom.

- V-S-V diagramy - vychádzajú z metódy vývojových diagramov a s vhodné predovšetkým na riešenie algoritmov celých úloh skladajúcich sa zo sekvencií po sebe nasledujúcich krokov s minimom rozhodovania.

- Rozhodovacie tabul'ky - sú jedným z relatívne najjednoduchších, ale vel'mi účinných nástrojov pre racionalizáciu práce pri analýze a syntéze systému a pri návrhu algoritmu. Na rozdiel od vývojových diagramov sú ideálnym nástrojom na modelovanie rozhodovacích algoritmov. Používajú sa na riešenie problémov v oblasti ekonomiky, techniky, v právnej a sociálnej oblasti a pod..

\section{Tvorba algoritmu}

Vo všeobecnosti má l'udská mysel' schopnost' uvažovat' jasne a presne len o jednoduchých a nie príliš zložitých objektoch. Pri opise štruktúry zložitejších objektov obyčajne sa postupuje po krokoch, t. j. uskutočňuje sa postupnú dekompozíciu objektu metódou top - down. Výsledkom dekompozície je hierarchická štruktúra zložená 
z jednotlivých prvkov, ktorú možno znázornit' najlepšie stromovým grafom. Dekomponovaným objektom môže byt' navrhovaný systém, program, dátová základňa, jednotlivé súbory, vety a pod..

Pri návrhu algoritmu výberu pripojenia do internetu boli využité tzv. vývojové diagramy. Ide o najbežnejší spôsob zápisu algoritmu pomocou prehl'adných blokových schém a symbolických obrazcov.

Symbol predstavuje jednoduchý alebo zložený príkaz alebo výraz. Jedná sa o najčastejšie používaný prvok.

Symbol reprezentujúci postupnost' krokov, ktorá je znázornená iným spôsobom alebo inou čast'ou algoritmu. Slúži na zjednodušenie algoritmu.

Symbol predstavuje príkaz vetvenia programu alebo definíciu podmienky.

Symbol označujúci začiatok a koniec algoritmu.

Symbol označujúci začiatok alebo ukončenie cyklu v programe.

Symbol označujúci vstup údajov do algoritmu.

Symbol označujúci výstup údajov z algoritmu.

Obr. 1. Základné symboly vývojových diagramov [5]

\section{Stanovenie kritérií pre výber pripojenia do siete internet}

$\mathrm{V}$ prípade, že sa podnik rozhodol vybodovat' si pripojenie do siete internet, je potrebné už vopred si stanovit' kritériá, podl'a ktorých si bude konkrétne pripojenie vyberat'. Na Slovensku existuje vel'a lokálnych a niekol'ko národných poskytovatel'ov siete internet. Pokial' si podnik nestanoví určité kritériá, pravdepodobne bude mat' problém sa v tak širokej ponuke zorientovat'. Medzi tri základné kritériá možno identifikovat' cenu, kvalitu a technologické požiadavky na pripojenie [2].

Cena

U väčšiny l'udí (užívatel'ov, spotrebitel'ov) je práve cena rozhodujúcim faktorom pri rozhodovaní. Cena udáva hodnotu, ktorú je spotrebitel' ochotný zaplatit' za ponúkaný výrobok alebo službu. Vo všeobecnosti možno hovorit' o nákladoch súvisiacich so zriadením a prevádzkovaním siete internet. Tie je možné rozdelit' nasledovne:

- Jednorazové náklady - náklady na zriadenie a vybudovanie siete (switche, routre, kabeláž - v závislosti od vybranej technológie pripojenia) a samozrejme za prácu (ocenenie práce konkrétneho pracovníka, ktorý danú siet' vybuduje, tieto náklady bývajú často krát prenesené do cien jednotlivých komponentov potrebných na vybudovanie siete).

- Mesačné náklady - tieto náklady súvisia už priamo s prevádzkou siete. Provider si môže stanovit' mesačné poplatky za služby nasledovne:

o fixné $\mathrm{N}$ - užívatel' platí fixný mesačný poplatok za pripojenie bez ohl'adu na objem prenesených dát alebo času, počas ktorého využíval služby siete.

o variabilné $\mathrm{N}$ - cena za pripojenie sa odvíja bud' od času, ktorý strávi užívatel' v sieti internet alebo je závislá od objemu dát, ktoré užívatel' prostredníctvom siete preniesol. Tieto náklady sa väčšinou skladajú $\mathrm{z}$ fixnej časti (určitý predplatený objem dát) a z variabilnej časti (poplatok za všetky dáta, ktoré boli prenesené nad stanovený objem). 
Cena úzko súvisí s pojmom kvalita. Pretože ako je vel'mi dobre známe z reálneho života, nie vždy všetko čo je lacné, je zároveň aj kvalitné a naopak, nie všetko drahé musí byt' zároveň aj kvalitné.

\section{Kvalita}

Kvalita je vlastnost', ktorá svojim spôsobom hodnotí produkt (službu). Táto vlastnost' však môže byt' dost' subjektívna. Kvalitu môžeme hodnotit' z rôznych hl'adísk. Kvalitu hodnotíme hlavne podl'a toho, na čo je konkrétny produkt určený. Zákazník môže, podl'a môjho názoru, kvalitu považovat' za určitý súbor vlastností s rôznou prioritou. Pričom dôležitejšie vlastnosti sa odvíjajú hlavne od toho na čo je produkt určený. Priorita zvyšných vlastností závisí už na konkrétnom zákazníkovi. Odborná definícia vraví, že kvalita je definovaná ako charakteristický znak alebo vlastnost' uspokojujúca potrebu alebo určenie. Je potrebné si vopred stanovit', aké služby a vakom rozsahu očakávam od mnou zvoleného providera. Medzi základné služby by malo patrit' zriadenie siete, jej prevádzka a samozrejme údržba siete v požadovanej kvalite [1].

\section{Technologické požiadavky}

Technologické požiadavky sú vel'mi individuálnou záležitost’ou. Preto je potrebné si vopred stanovit', na čo bude siet' slúžit' a tomu prispôsobit' aj jej technologické parametre. (komerčné alebo súkromné dedikovanie siete) Od tohto sa potom odvíja požiadavka na rýchlost' a na objem prenesených dát.

Výber technológie pripojenia samozrejme závisí aj na mnohých iných faktoroch, napr. geografické (nie všade je možné realizovat' každé so spomínaných pripojení) alebo to môžu byt' rôzne stavebné bariéry a pod.. Preto je potrebné si stanovit' požiadavky so zvážením všetkých možných faktorov, ktoré by mohli realizáciu siete ovplyvnit’.

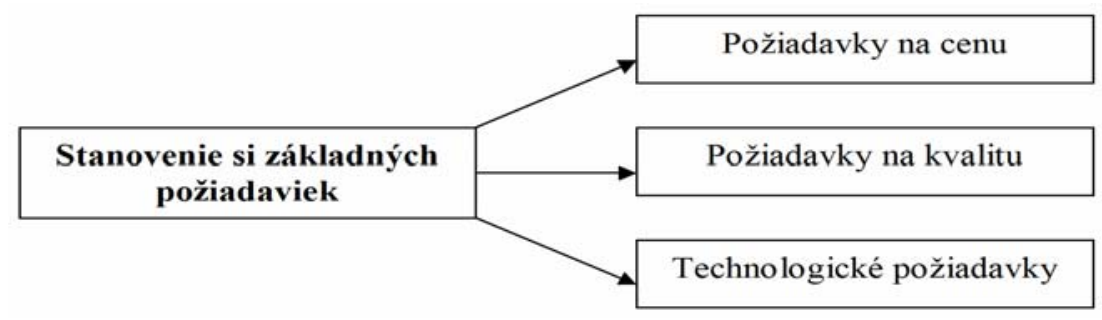

Obr. 2. Stanovenie si základných požiadaviek

\section{Výber poskytovatel'a služieb siete internet}

Výber vhodného providera na zriadenie pripojenia do siete internet zohráva dôležitú úlohu pre plnenie jej d'alších úloh (úloha distribučnej cesty). Pred samotným výberom providera je vhodné urobit' si prieskum trhu a možností v lokalite, kde sídli firma. Vel'mi jednoducho sa dajú získat' informácie napr. z webu alebo sa môžeme s našimi otázkami obrátit’ na našich známych, o ktorých vieme, že už takéto pripojenie majú zrealizované. (Pozn. z osobných skúseností (ale to je iba subjektívny názor) možno odporučit', že pre malé a stredné firmy je vhodné nechat' si zrealizovat' pripojenie prostredníctvom lokálnych providerov (ak však v danej lokalite nejakí provideri pôsobia)). Ak nie, potom existujú tzv. národní provideri (pokrytie takmer celého územia SR), ako napr. T- com, Orange alebo UPC Chello [3].

Pokial' už sú zistené informácie o tom, ktorí provideri pôsobia v konkrétnej lokalite, je potrebné realizovat' komparáciu cenových ponúk a rozsahu poskytovaných služieb. Cenníky služieb je možné nájst' na firemných stránkach providerov alebo je možnost' osobne navštívit' konkrétnych providerov priamo v mieste sídla ich spoločnosti. 


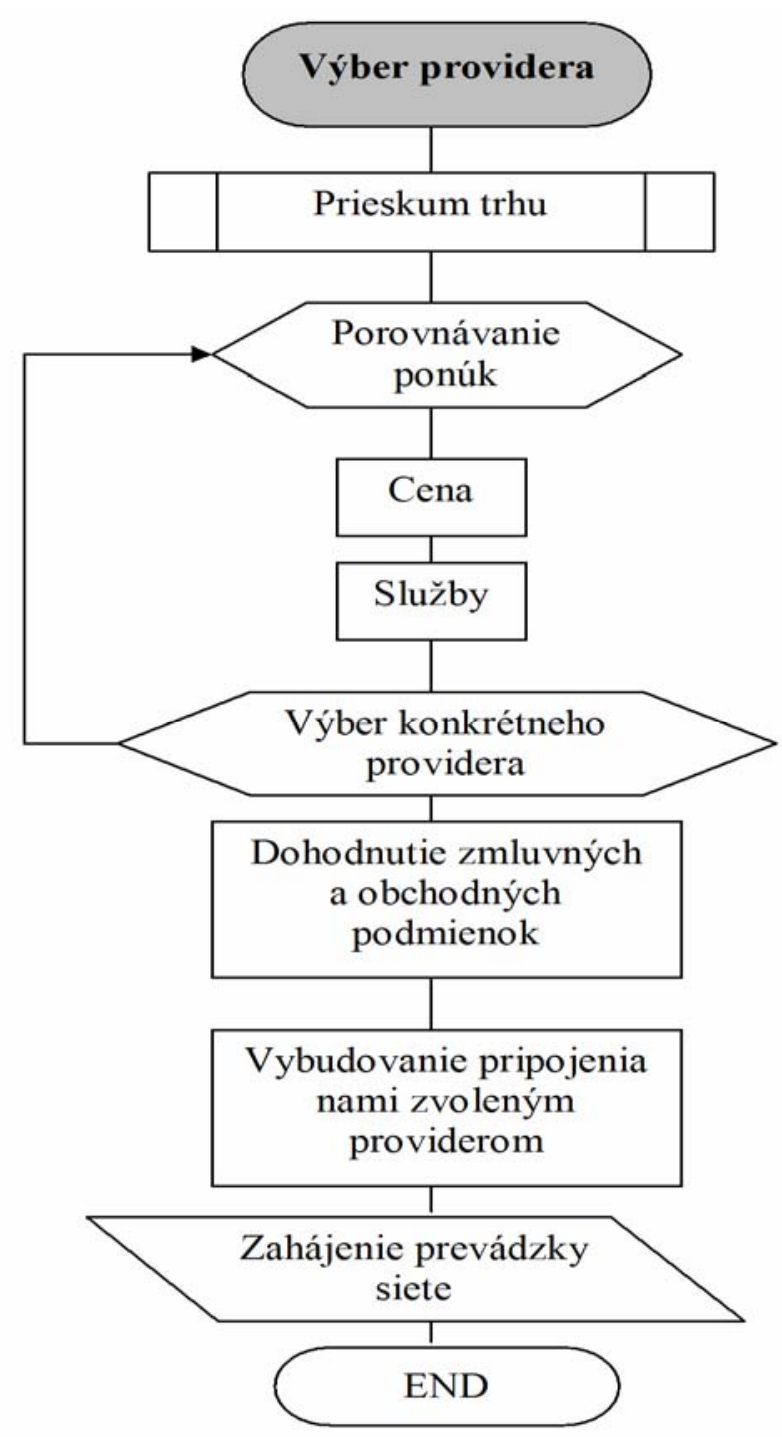

Obr. 3. Algoritmus výberu providera [4]

Ak sú získané informácie vyhodnotené (prehl'ad aké služby a za aké ceny ich provideri poskytujú) je potrebné uskutočnit' rozhodnutie, ktorého providera si na zriadenie pripojenia $\mathrm{k}$ internetu vyberieme. Na záver už zostáva len nadviazat' osobný kontakt s providerom, dohodnutie obchodných a zmluvných podmienok. Celý proces nakoniec vyústi do vybudovanie pripojenia do internetu $\mathrm{v}$ podniku. 


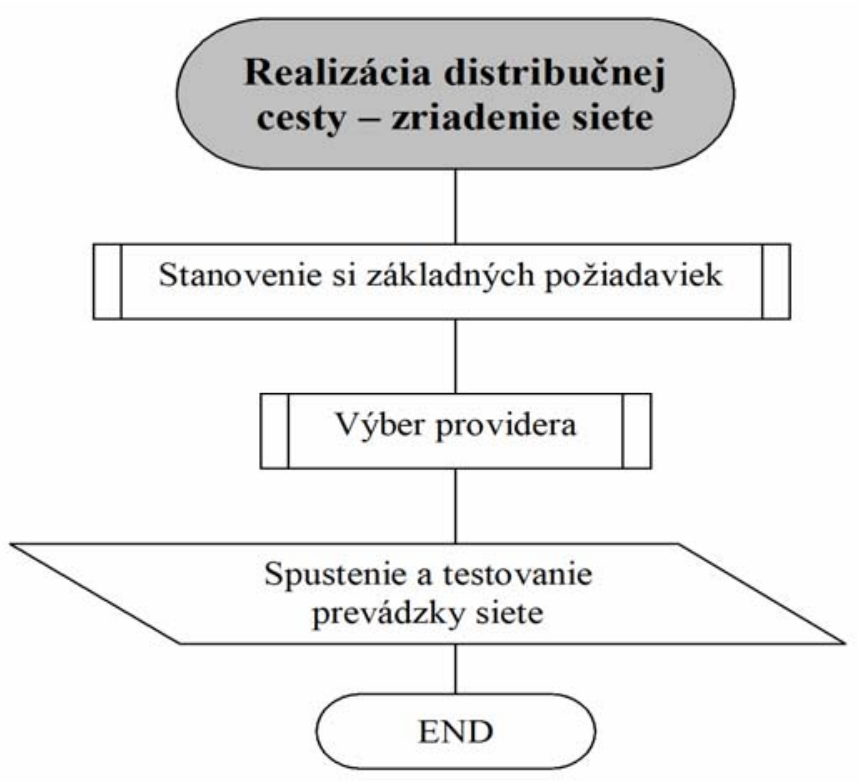

Obr. 4. Zjednodušený algoritmus realizácie distribučnej cesty (pripojenia do internetu)

\section{Záver}

Ak je siet'ové pripojenie vybudované, je možné spustit' jeho prevádzku a začat' siet' využívat' na komerčné účely. Je vhodné zo začiatku sledovat', či celá siet' funguje, tak ako má, napr. či rýchlost' pripojenia je taká, aká bola dohodnutá v zmluvných podmienkach (napr. prostredníctvom speedmetra na www.dsl.sk), či je siet'ové pripojenie stále (či nedochádza k výpadkom siete) a ak všetko korektne funguje, je vhodný čas na realizáciu vybranej emarketingovej stratégie.

\section{Literatúra}

[1] ČOREJOVÁ, T.: K problematike trhu elektronickej komunikácie z pohl'adu zákazníka, In: Ekonomika firiem 2004 : Michalovce, 16.-17.9.2004. II. diel. - Košice: Podnikovohospodárska fakulta v Košiciach, 2004. - ISBN 80-225-1879-4. - S. 506-509.

[2] MADLEŇÁK, R.: Elektronický obchod, Žilinská univerzita v Žiline, Žilina, 2004, 160 str., ISBN 80-8070-192-X

[3] MADLEŇÁKOVÁ, L.: Hodnotenie postavenia telekomunikačných operátorov, In: Doprava a spoje - ISSN 1336-7676. - č. 1, 2007, 8 s.

[4] SENKOVÁ, P.: Algoritmus aplikovania informačno-komunikačných technológii a emarketingu v oblasti malého a stredného podnikania, diplomová práca, Katedra spojov, 2007

[5] VACULÍK, J.: Telematické služby; EDIS, Žilinská univerzita, Žilina, 1998, ISBN 80$7100-530-4$

\section{Grantová podpora}

1/1265/04 VEGA MŠ SR a SAV - Výskum siet’ových procesov v rámci odvetvových zoskupení firiem SR

1/2591/05 VEGA MŠ SR a SAV - Vplyv výberu efektívnej stratégie na udržiavanie konkurencie schopnosti podniku $\mathrm{v}$ rámci liberalizácie poštových trhov

BIL/NEM/SR/ŽU/06 - Pravidla dodržiavania sút'aže na trhu elektronických komunikácií 